\title{
EU Soft Power in the Eastern Neighborhood and the Western Balkans in the Context of Crises
}

\author{
Artem Patalakh \\ Graduate School of Social and Political Sciences, \\ University of Milan \\ via Pace 10, \\ Milano 20122, Italy \\ E-mail: artem.patalakh@unimi.it
}

\begin{abstract}
The article aims to assess a change in the EU's soft power in the Western Balkan and Eastern Partnership states in the light of the crises the bloc has undergone in recent years. Generally agreeing with the common argument that the EU's attractiveness for those countries has decreased, the author challenges the popular wisdom that such a decrease is likely to reverse those states' pro-EU foreign policy orientations. To prove it, the author applies Joseph Nye's and Alexander Vuving's "power currencies" approach to operationalize soft power, considering the bloc's attraction as a combination of "brilliance" (the actor's relationship with its work), "benignity" (the actor's relationship with other actors) and "beauty" (the actor's relationship with values and ideas). Elaborating on the crises' influence on each of these currencies, the author shows that their lessening, first, has mainly taken place in absolute rather than relative terms, so the EU's attractiveness remains strong compared to that of its competitors, and second, it has primarily affected the bloc's soft power potential rather than its actual behavior towards the target countries.
\end{abstract}

Keywords: attraction, Eastern Partnership, European Union, power currencies, soft power, Western Balkans 


\section{Introduction}

Traditionally, the EU, "an economic giant and political dwarf" was considered as an international actor possessing significant "soft power", that is, having considerable "ability to get what you want by attraction rather than coercion or payment" (Nye, 2004, p. x). Specifically in the case of the EU, soft power takes the forms of "normative" (Manners, 2002) and "civilian power" (Telò, 2007), both of which imply the bloc's non-coercive influence over other IR actors owing to the attractiveness of different aspects of its developmental model for them. ${ }^{1}$ The usefulness of soft power for the EU arguably lies not only in foreign but also in domestic policy: to exemplify, it has been argued that discourse on soft power can aid the EU in handling its "capability-expectations gap" (Tulmets, 2007) and facilitate building a stronger European identity (Michalski, 2005).

In recent years, however, the EU has been undergoing several consecutive challenges which, some argue, have led to a decline in the bloc's soft power. To name a few, the EU has experienced the 2011 eurozone crisis, the 2015 Greek government-debt and refugee crises, the 2016 Brexit - to say nothing of systemic crises that can hardly be located chronologically, such as the NorthSouth divide and a rise of far-left, far-right parties and populist regimes. The soft power decline is argued to especially apply to Eastern Partnership (EaP) members and Western Balkans states, which are all engaged in certain forms of formal rapprochement with the EU: the former (Georgia, Moldova and Ukraine) have signed EU Association Agreements, whereas the latter are either official candidates to accession (Albania, Kosovo, Macedonia, Montenegro and Serbia) or are on the way to obtaining its status (Bosnia and Herzegovina and Kosovo). ${ }^{2}$ In particular, Müller (2016, pp. 363-364) and Smith (2014, p. 106) contend that the EU tends to turn its attention to its internal economic and financial matters at the expense of foreign policy goals. Sadowski (2013, pp. 41-43) argues that the crises result in both the EU's and the target states' businesses getting less interested in one another, which might eventually reverse their elites'

Following Nielsen (2016, pp. 8-9), I find the concept 'soft power' more preferable to 'civilian' or 'normative' power, since, first, it is a more widespread concept in the world IR scholarship (the other two are rather EU-contextual) and second, it enables to more fully take account of various dimensions of an IR actor's attractiveness for other actors.

2 Hereinafter, I will refer to the mentioned states as 'target states' or 'target countries'. I intentionally exclude two EP members - Belarus and Azerbaijan - from further analysis, because they stand out in their political regimes and geopolitical orientations: unlike the other target states, Belarus and Azerbaijan remain highly authoritarian and have never expressed interest in concluding an EU Association Agreement. 
commitments to mutual rapprochement. He also notes that a widening split on internal political issues among EU Member States leads to the bloc's relations with its neighbors in general and its enlargement in particular being of lower relevance, which slows down the pace of integration and, in turn, negatively affects the target countries' determination to align with the EU (Sadowski, 2013, pp. 43-44).

Furthermore, researchers express certain fears that the EU's weakening soft power may turn out to be unable to compete against Russia's hard power influence, its use of coercion and pressure on the target countries (Sadowski, 2013, pp. 44-46). IR students also have pointed out a relative decline of the EU's against the backdrop of US soft power that improved under President Obama (Smith, 2014, p. 106), as well as the EU's inconsistency in its promotion of values, which manifests itself in "support for authoritarian regimes in the name of stability" (Smith, 2014, p. 107). Finally, scholars argue that an organization facing one crisis after another no longer poses an attractive model to follow and, hence, cannot teach its neighbors how to live any more, which brings about the need to search for a different approach to the target countries (Popescu, 2011). This article, however, aims to partially specify and partially challenge these speculations. Not doubting that the crises have diminished the EU's attractiveness in general, I argue that such speculations primarily rest on the exaggeration of the effect of the crises on EU soft power. I contend that the diminution of the bloc's attractiveness in the target states, first, has mostly influenced its soft power assets rather than real behavior toward the target countries and second, has mainly taken place in absolute, rather than relative terms and, hence, is unlikely to entail any significant reverse of those countries' pro-EU orientations.

Methodologically, this article is built upon three core premises. First, I account for the fact that both groups of states have been arenas of Russia-EU geopolitical competition (see Rostoks, 2015; Żornaczuk, 2016) and in consequence, face a so-called "civilizational choice" between the two actors. The presence of the agent's (in this case, the EU's) competitor (Russia) is likely to impact the former's attractiveness as perceived by the subject (in this case, the target states) and, thus, influence the latter's foreign policy choices (for details, see Patalakh, 2016, pp. 100-103). Second, I apply a subject-centred rather than agent-centred approach to soft power analysis, that is, I focus on the EU's characteristics of which the target states may conceive as attractive (for other studies employing a similar approach, see Rohrbacher \& Jeníčková, 2011; Rostoks, 2015), rather than considering soft power not as an intentional strategy led by the agent to attract the subject, like most studies do (e.g., Nye, 2004; Michalski, 2005; Patalakh, 2016). 
Third, I operationalize soft power around three so-called "power currencies"benignity, brilliance and beauty - that, according to Alexander Vuving (2009, pp. 8-12) and Joseph Nye (2011, p. 92), constitute different dimensions of the agent's attractiveness for the subject (see Table 1). Brilliance refers to the agent's relationship with its work, which in international relations may manifest itself in high living standards, stable economy, successful and effective solution of internal problems, etc. Brilliance induces the subject to admire the agent and as a result, view the latter as attractive to follow. Benignity pertains to the agent's relationship with other actors and especially with the subject: the agent's generous, kind, supportive behavior toward the subject increases the former's attractiveness via the production of gratitude and sympathy. Finally, beauty denotes the agent's relationship with values and ideas: if the agent actively follows and promotes certain ideas that the subject considers as good, the latter gets inspired and, again, regards the agent as attractive to align to. ${ }^{3}$

\section{Table 1. Soft power/attraction "currencies"}

\begin{tabular}{|l|c|c|c|}
\hline $\begin{array}{l}\text { Power } \\
\text { "currency" }\end{array}$ & $\begin{array}{c}\text { Corresponding dimension of } \\
\text { the agent's life }\end{array}$ & $\begin{array}{c}\text { Psychological } \\
\text { mechanism }\end{array}$ & $\begin{array}{c}\text { Foundation in basic human } \\
\text { tendencies }\end{array}$ \\
\hline Brilliance & $\begin{array}{c}\text { The agent's relations } \\
\text { with its work }\end{array}$ & $\begin{array}{c}\text { First admiration, } \\
\text { then imitation }\end{array}$ & $\begin{array}{c}\text { Learning from others' } \\
\text { successes }\end{array}$ \\
\hline Beauty & $\begin{array}{c}\text { The agent's relations with } \\
\text { ideas, values and visions }\end{array}$ & Inspiration & $\begin{array}{c}\text { Uniting with those having } \\
\text { similar values/goals; the } \\
\text { need for moral support and } \\
\text { aesthetic experience }\end{array}$ \\
\hline Benignity & $\begin{array}{c}\text { The agent's relations with other } \\
\text { actors, particularly with the } \\
\text { subject of soft power }\end{array}$ & $\begin{array}{c}\text { Gratitude and } \\
\text { sympathy }\end{array}$ & Reciprocal altruism \\
\hline
\end{tabular}

Source: Based on Vuving, 2009, pp. 8-12

3 Remarkably, this classification of attractiveness into three types from the subject's perspective should not be viewed as a cursory theory: in fact, it matches a long tradition in psychology that discriminates three categories of human mind, that is, cognition, affection and conation (see Hilgard, 1980), and subsequently, human attitudes - into cognitive, affective and conative (Eagly \& Chaiken, 1993). This point is mirrored in various areas of social sciences: to cite some examples, Habermas (1984) distinguishes between the objective, social and subjective worlds of reality; Eisenegger and Imhof (2008) single out the functional, social and expressive kinds of reputation; Risse (2000) distinguishes between three logics of social action, to wit, logic of arguing, logic of consequentialism and logic of appropriateness. 


\section{Impact of crises on EU soft power}

\subsection{Brilliance}

An analysis of EU's brilliance first necessitates the understanding of the bloc's actions and qualities that are likely to shape other actors' perception of its achievements. Most intuitively, for an integration group to be considered as "brilliant", it should prove itself as having functional institutions and members that are able to come to agreements and abide by regulations. Additionally, any organization is assessed on the basis of the aims for the pursuance of which it exists. According to Article 3 of the Lisbon Treaty, the EU has been established to conduce to peace and the economic (internal market, competition, economic growth) and social (sustainable development, social progress, full employment, environmental protection, well-being) development of its Member States as well as their scientific and technical advancement.

Brilliance is evidently the aspect of the EU's soft power that has been directly affected by the crises, due to which the EU has become a less attractive model to align to. To name a few consequences, the eurozone crisis exacerbated NorthSouth disparities in the EU and brought Greece to the brink of renouncing the euro in 2015. The inability of the International Coalition in Syria, partly comprised of EU member countries, to efficaciously combat ISIS entailed an unprecedented influx of refugees to the EU, which, in turn, provoked a rise of nationalism inside the bloc, uncovered a wide gap in EU members' approaches to migrants and was one of the causes of Brexit. A series of terrorist attacks across the EU in 2015-2017 have also generated debates on the effectiveness of the bloc's refugee policies and border controls in combating terrorism. All in all, it does not appear an overstatement to argue that the EU has come out of the crises weaker, poorer and less united than before.

However, a broader look at the components of the EU's brilliance, instead of a focus on particular events, leads to doubts regarding the truthfulness of the above-mentioned argument that the EU no longer presents an attractive model to follow. First, except in the case of Brexit, where the EU's precedent endeavors to negotiate appropriate conditions for the UK to stay in the Union had not proven effective, the EU has succeeded in resolving most crises diplomatically, via negotiations: the bloc managed to find suitable terms for Greece to stay in the eurozone and conclude a deal with Turkey that abated a further influx of refugees. Even Brexit, with its definitely negative impact on EU's economic power and international image, is likely to have a positive impact on EU integration by strengthening unity among EU Member States and encouraging 
EU elites to conduct needful reforms (Oliver, 2017). Second, the crises have not affected the EU's position as the region's most progressive power regarding socio-economic standards and indicators. In the Social Progress Index, all the target countries rank lower than EU Member States (Porter \& Stern, 2016, pp. 17-18). The same applies to the Human Development, Corruption Perception and Environmental Performance Indexes with Montenegro, Georgia and Armenia being the sole exceptions correspondingly (UNDP, 2016, pp. 198201; Transparency International, 2016; Hsu 2016, pp. 18-19). Third, the crises have hardly affected the EU's position as the region's most advanced actor scientifically and technologically: for instance, the 2016 Times Higher Education Index includes hundreds of EU Member States' universities; concurrently, as for the target countries, only one Serbian and two Ukrainian universities are present there, and they rank low, from 600 to 800 (Times Higher Education, 2016). EU members also outrank all the target countries, except Serbia, in ICT Development Index (ITU, 2016, p. 12).

Moreover, EU's brilliance looks even higher against the background of its competitors in the region, the most important of which is the Russia-led Eurasian Economic Union (EAEU). Currently made up of Armenia, Belarus, Kazakhstan, Kyrgyzstan and Russia, that organization is considered to be the most promising integration project in the post-Soviet space (e.g., Zagorski, 2015). The EAEU's performance to date, however, seems to have only strengthened the relative attractiveness of the EU for the target countries. To draw a parallel, despite its relative painfulness, the 2011 eurozone crisis was comparatively short and turned into an economic growth already in 2013: in fact, Greece was the only EU member exhibiting no economic growth in 2015 (Eurostat, 2017). In the EAEU, the unprecedented depreciation of the Russian rouble in 2014 entailed a similar crisis in its other member states, coupled with the total GDP falling from 2,566,4 billion dollars in 2013 to 2,375,2 billion in 2014 to 1,581,7 billion dollars in 2015 (Eurasian Economic Commission, 2016, pp. 18-19). Importantly, economists consider it scarcely possible for the rouble to win back its position and for the Russian economy - to recover fast and steadily given currently low oil prices and unfavorable investment climate (see Movchan, 2017). Furthermore, while in the EU, the common market has led to strengthening economic ties between its Member States - statistically, since 2009 there has been a constant growth in intra-EU trade (Eurostat, 2016) - in the EAEU, the trend over the last five years has surprisingly been the opposite, towards a decline in mutual trade (Eurasian Economic Commission, 2016, p. 24).

Additionally, unlike in EU case, membership in the EAEU does not presuppose any adherence to particular values. As a result, the union consists of countries 
that significantly vary in their commitments to democracy, political freedoms, and market economy (Roberts \& Moshes, 2015). Coupled with the weakness of the Eurasian Economic Commission, the bloc's supranational institution, as well as the fact that EAEU members have strong "regime identities", the lack of common values often entails strong difficulties for the bloc when it comes to finding a consensus between its member states (Roberts \& Moshes, 2015), albeit it consists of only five members against the EU's 28 ones. While EU Member States - with difficulties, but still — managed to find a consensus on how to react to the Ukrainian crisis, Russia's EAEU fellows not only refused to officially recognize its annexation of Crimea and join its food embargo against the EU, but also tried to take advantage of sanctions imposed on Russia: Belarus, for example, started to sell EU food to Russia with Belarusian labels, which entailed several "trade wars" between the two countries (Roberts \& Moshes, 2015). Lastly, unlike the EU, the EAEU, to a great extent, rests on hard rather than soft power and serves Russia's goals. Indeed, EAEU members tend to complain that its Commission is dominated by Russian officials who pursue Russian interests (Daly, 2014). Moreover, Armenia and Kyrgyzstan are argued to have been coercively pushed into the bloc and not joined it voluntarily: for instance, one of the reasons why Armenia in September 2013 opted for an EAEU membership instead of an EU Association Agreement was thatMoscow had threatened Erevan with increasing gas prices by $70 \%$, banning Armenian exports and blocking private transfers of money to Armenia, deporting Armenians working in Russia and providing offensive weaponry to Azerbaijan (for details, see Patalakh, 2017, pp. 8-9). This all is contrary to the EU which, first, can hardly be blamed for coercing other countries to enter it, given how long its candidates have to wait until being accepted, and, second, is not dominated by any single country, though some of its Member States do have greater influence than others.

\subsection{Beauty}

Regarding ideas and values, one can single out two main aspects that constitute the EU's attractiveness for the target countries. First, Article 21 of the Lisbon Treaty obliges the bloc to promote democracy and human rights which are, first, according to surveys, considered important by the majority of Europeans, including the citizens of the target countries (Ferrin \& Kriesi, 2014, p. 7), and second, regarded as universal values internationally: it is no coincidence that even the world's most authoritarian regimes constantly endeavor to present themselves as committed to democracy and human rights. For the target countries, all of which are on their way towards democracy and rule of 
${ }^{l a w^{4}}$, the fact that the EU rests upon these values and is one of their foremost international promoters (Treaty of Lisbon, Art. 3) is an indicator of the bloc's progressiveness, which makes rapprochement with it prestigious. Second, this progressiveness allows the EU to be viewed as contrary to autocracy in general and Cold War Communist regimes in particular. It is especially significant for such states as Georgia, the foreign policies of which are largely guided by their European identities rather than pragmatic cost-benefit calculation (see Kakachia \& Minesashvili, 2015; Chochia \& Popjanevski, 2016). ${ }^{5}$ Alignment with the EU fulfils their aspirations to belong to the Western club of "civilized" states, detaching them from their Communist past and contemporary Russia which they conceive of as outdated, underdeveloped.

Both aspects appear to be affected by the current crises. First, the crises is one of the factors that have triggered a rise of populist movements in the EU (Bröning, 2016). A number of them, such as Viktor Orbán's Fidesz in Hungary and Jarosław Kaczyński's Law and Justice in Poland, have utilized anti-EU rhetoric to assume power and consolidate their grip on it, swerving from democracy and liberal values, while the EU, in turn, has turned out incapable of disciplining its Member States for illiberal turns (Halmai, 2017). Second, the crises have affected the EU's image as an opposer to Russia's autocracy, contributing to the activation of so-called Putin's "Trojan horses" in EU relations with Russia, that is, actors inside the bloc that systematically express attitudes and take steps favorable for Russia (e.g., oppose imposition of sanctions on Russia, conclude deals with

4 To date, no target state is deemed authoritarian in international indexes. Democracy Index regards Macedonia, Moldova, Montenegro and Serbia as flawed democracies, while Albania, Armenia, Bosnia and Herzegovina, Georgia and Ukraine - as hybrid regimes (EIU, 2016, pp. 4-8). Freedom House (2017, pp. 20-24) defines all the target states as partly free, except Serbia which is considered free.

5 In principle, for different states, the EU's attractiveness may be primarily benignitydriven, beauty-driven, or brilliance-driven, which corresponds to the three possible logics of EU legitimation found in the theory, that is, contextual, conceiving of the EU as a value-based community, instrumental, deeming the EU as a problem-solving entity, or communicative, regarding the EU as a rights-based union (Eriksen \& Fossum, 2004, pp. 437-448). Georgia is an illustrative case of the first one, while Serbia, whose affiliation with the EU is usually thought of as driven by the utilitarian desire to gain material benefits (Economides \& Ker-Lindsay, 2015), seems exemplary of the second one. Importantly, motives for alignment may alter over time: to illustrate, for Ukraine, which traditionally used to pragmatically balance between Russia and the EU, a pro-European orientation turned into a comprehensive national idea after it suffered Russia's aggression in March 2014 (Tsybulenko \& Pakhomenko, 2016). I abstain, however, from strictly subdividing all the target states into three groups by the logics of their integration intentions, since, first, relevant case studies are missing on some of them and, second, most of them are likely to display a mix of several logics with no single logic strictly prevailing over the others. 
Russia that contradict EU policies, etc.), despite the EU's common critical stance on Putin's regime for systemic human rights violations and aggression in Ukraine (Orenstein \& Kelemen, 2017). Putin's "Trojan horses" in the EU are present at the level of Member States, including not only those ruled by populist leaders/parties, such as Greece (Tsipras' Syriza) and Hungary (Orbán's Fidesz), who share Putin's anti-EU rhetoric, but also liberal states, such as Cyprus and Italy, whose pro-Putin moves mostly spring from their close economic ties with Russia, which they regard as especially crucial to keep in the period of economic problems. Though those "Trojan horses" constitute a minority of EU members, the bloc is not always able to overcome their opposition, which tends to sap its reputation as a human rights promoter: for example, due to Italy's protest, the EU did not place new sanctions for Russia's violent bombing of Aleppo in October 2016, which was being backed by Germany, France and the UK (Emmott \& Guarascio, 2016). Also, Russia's "Trojan horses" include a number of far-left and far-right political parties across the EU, such as France's National Front, Italy's Five Star Movement, etc. (see Laruelle, 2015). Those parties are not ruling any Member States, but sometimes have majorities in regional parliaments, which tends to make their actions noticeable: for instance, in May 2016, the council of the Italian region of Veneto, dominated by the far-right Northern League, issued a declaration which recommended the Italian government to recognize Crimea as a Russian territory (Murtazina, 2016).

Nonetheless, under close inspection, it becomes clear that the aforementioned losses in the EU's beauty barely surpass its attractive aspects. First of all, despite a decline in freedom and democracy in absolute terms, the EU is still relatively democratic and free: even the bloc's illiberal democracies, such as Poland and Hungary, rank higher in Democracy Index than any of the target countries (EIU, 2016, pp. 4-8). Second, the rising pragmatism concerning human rights promotion and relations with Russia seems to play—perhaps, surprisingly —into the hands of not only "pragmatic", but also more identity-driven states which tend to drop ideational concerns when it comes to matters of security and economic development. In August 2015, for instance, the then Georgian Prime Minister Irakli Garibashvili expressed his opposition to his country's joining sanctions against Russia, arguing that such would hinder the normalization of GeorgianRussian relations (Jones, 2015). In a similar vein, in November 2014, the then Montenegrin Prime Minister Milo Đukanović, known as a firm supporter of his country's entering the EU and NATO, spoke in favor of lifting the Russia sanctions for economic reasons (Prekic, 2014). Third, in fairness to the EU, the aforesaid growth of pragmatism in the bloc seems limited and in fact, the union has several times proved in practice that it is not ready to sacrifice its fundamental principles 
for attaining tactical goals: to illustrate, to Ukraine's satisfaction, the EU never lifted its sanctions in return for Russia's military operation against the Islamic State, on which Putin was reportedly counting in autumn 2015 (Bodner, 2015).

Finally, despite their pro-Russian moves, Cyprus, Greece, Hungary, and Italy have constantly shown support for the rapprochement of the target countries with the EU, which even for the identity-driven states is undoubtedly a matter of higher importance. At the same time, the "Trojan horses" among EU populist movements, such as the French National Front and the Italian FiveStar Movement, have continuously opposed accepting new Member States and concluding new association agreements. Nevertheless, to date, such movements do not significantly impact the bloc's foreign policy and it is unclear how they will act should they win office: one can agree with Tetlock (1981, p. 207) that "it is no simple matter to predict how prospective leaders will act once they come to power. Upon the triumph of their cause, seemingly fanatical revolutionaries sometimes become pragmatic and flexible statesmen".

\subsection{Benignity}

Similarly to beauty, the EU's benignity for the target countries primarily stems from two sources. First, in the framework of the Pre-accession Assistance and European Neighborhood instruments, the bloc financially supports their advancement of democracy and rule of law, public administration, justice and social sector reforms, empowerment of small and medium-sized enterprises and civil society organizations, etc. It is worth noting that, though Nye considers payments to generally represent a form a hard power, he argues in favor of contextual understanding of soft power resources, acknowledging that "resources often associated with hard power behavior can also produce soft power behavior depending on the context and how they are used" (Nye, 2011 p. 21). Given the context of the EU's financial assistance, I argue that it can be fairly deemed not as simply a payment for loyalty, but a form of true benignity, soft power. First, the EU tends to provide material assistance not only to loyal states, but even to a number of self-confessedly unamicable regimes: to illustrate, the EaP's beneficiaries include autocratic Azerbaijan and Belarus and even Russia was offered membership in the program, but rejected it. Also, the bloc has kept financing its projects in Armenia even after its President Serj Sargsyan announced in September 2013 that Armenia would enter the EAEU instead of signing an EU Association Agreement (Kostanyan \& Giragosian, 2016). To draw a parallel, Russia in a similar case replied by annexing Crimea and arming rebels in Donbas after Ukraine had opted for the EU and not the EAEU. Second, 
the EU is sometimes noted for not substantially accentuating financial support in its public diplomacy, due to which it tends to remain unnoticed: as a result, in $2014,47 \%$ of Serbians reportedly believed that Russia was the largest supplier of aid to their country, although in reality, $89.49 \%$ of foreign aid to Serbia was coming from the EU and the US (Szpala, 2014, p. 3).

Despite the aforementioned fears that internal crises in the EU make its rapprochement with the target countries less topical, distracting the bloc's attention and resources from them, facts prove the opposite. Figures given in Tables 2 and 3 clearly show that the EU has been increasing its financial assistance to them and is planning to increase more. Furthermore, the bloc seems to be paying increasingly more attention to the development of the target countries, the state of their reforms and implementation of EU requirements, trying to enhance the effectiveness of EU funds there. With this aim in view, the bloc's assistance to its candidate countries in 2014-2020, compared to the period of 2007-2013, provides for "a stronger ownership by the beneficiaries through integrating their own reform and development agendas", allowing "a move towards a more targeted assistance, ensuring efficiency, sustainability and focus on results" as well as "a more systematic use of sector budget support" (European Commission, 2016). Such principles of aid allocation sharply contrast with those of Russia, whose aid is known for aiming mostly to pay for loyalty and increase its economic leverage in the recipient state, not being strongly linked to how effectively the recipient state disposes of the aid and whether it complies with the terms of its provision. For instance, one study on Russia's assistance to Belarus observed that "in reality the decisions to disburse the individual instalments of an $\mathrm{ACF}$ EurAsEC $^{6}$ loan are highly politicised, and money has been paid out to Belarus despite its failure to fully meet the conditions of the loan" (Wierzbowska-Miazga, 2013, pp. 17-18).

The second aspect of the EU's benignity consists in aiding the countries that fall victim to other IR actors' hard power, contributing to their independent development and peaceful resolution of conflicts. To cite the most illustrative examples of this point, the EU supported the 1999 NATO operation aimed to save Kosovar Albanians from the repressions of the Milošević's regime; later, the bloc has actively assisted that region in its democratic transition and, since 2008, independent development. More recently, the EU strongly condemned Russian aggressions against Georgia in 2008 and Ukraine in 2014, which in the latter case was not limited to verbal political support of and financial assistance to the victim

6 The abbreviation stands for the Russia-controlled Anti-Crisis Fund of the Eurasian Economic Community, which existed before the launch of the EAEU. 
states, but went as far as to introduce economic sanctions against Putin's regime. In both cases, European leaders-Nicolas Sarkozy in 2008 and Angela Merkel and Francois Hollande in 2014 - mediated at peace talks. And in both cases, those mediations achieved relative success: both the 2008 Six Points Agreement and the 2014 Minsk Agreements managed to abate the conflicts' active phases.

Table 2. EU Financial assistance allocated to EP members under research in 2007-2020, in million euros

\begin{tabular}{|c|c|c|c|}
\hline EP member & $\begin{array}{c}\text { Financial assistance } \\
\text { in 2007-2010 }\end{array}$ & $\begin{array}{c}\text { Financial assistance } \\
\text { in 2011-2013 }\end{array}$ & $\begin{array}{c}\text { Financial assistance } \\
\text { in 2014-2020 } \\
\text { (indicative) }\end{array}$ \\
\hline Armenia & 98 & 157 & $741-906$ \\
\hline Georgia & 120 & 180 & $610-746$ \\
\hline Moldova & 210 & 273 & $610-746$ \\
\hline Ukraine & 494 & 470 & $828-1,013$ \\
\hline
\end{tabular}

Source: Rieker, 2016, p. 193

Table 3. Financial assistance allocated to EU candidate countries under research in 2007-2020

\begin{tabular}{|c|c|c|}
\hline EU Candidate & $\begin{array}{c}\text { Financial assistance under } \\
\text { IPA I (2007-2013) }\end{array}$ & $\begin{array}{c}\text { Financial assistance under } \\
\text { IPA II (2014-2020) }\end{array}$ \\
\hline Albania & 591.2 & 649.4 \\
\hline Bosnia and Herzegovina & 610.1 & $165.8^{7}$ \\
\hline Kosovo & 635.3 & 645.5 \\
\hline Macedonia & 615.1 & 664.2 \\
\hline Montenegro & 235.6 & 270.5 \\
\hline Serbia & $1,385.4$ & $1,508.0$ \\
\hline
\end{tabular}

Source: European Commission, 2016

Yet, this dimension of EU benignity suffers from weaknesses. To give a few examples, even though both Georgia and Ukraine appreciated the EU's support

7 For Bosnia, the EU limited financial assistance under IPA II to 2014-2017 because of the country's insufficient progress in the process of EU integration and the lack of national strategies in a number of sectors (European Commission, 2014). 
in the face of Russian actions, both found the taken measures insufficient, belated and indecisive (see Getmanchuk, 2014; Khidasheli, 2011, pp. 100-102). Armenia's decision to join the EAEU instead of signing an EU Association Agreement, for which the country had been prepared for four years, partially came due to the fact that Erevan regarded the EU to be unable (unlike Russia) to provide military support to Armenia in case of Azerbaijan's aggression (Vasilyan, 2017, pp. 33-34). Yet, the peculiarity of this aspect of attractiveness is that it presupposes that the bloc's soft power for the target countries hinges on its ability to use hard power against aggressive actors. However, this has hardly anything to do with the crises under analysis; rather, it is the EU's systematic weakness that was manifesting itself even in the 1990s-2000s, when its soft power was on its peak. Different explanations attribute this weakness to the bloc's shortage of military power, lack of coherence, will and strategic skills to use the power resources it possesses, insufficient social power grounded on shared concepts and perceptions of power (Forsberg, 2013, pp. 36-37). Against this backdrop, it seems an accomplishment that despite a rise of far-right and farleft parties, the European Parliament has adopted numerous resolutions strongly condemning Russian aggressions and, despite a growing number of populist regimes empathetic with Russian foreign policy, the European Council still managed to introduce, expand and prolong economic sanctions against Russia.

\section{Conclusions}

Twenty-eight years ago, Joseph Nye coined the concept of soft power while working on a book which aimed to challenge the then widespread idea about a decline in US power (Nye 2015, p. ix). This article is my humble attempt to employ this concept to pursue a similar objective, but in relation to the EU. The discussion above allows concluding that a decline in EU soft power seems to be stronger perceived inside the EU, where a series of crises, which has enjoyed considerable attention from the media, politicians and ordinary EU citizens, tends to engender an overall impression that EU soft power is going into decay. Yet, deemed from the perspective of Western Balkan and EaP states, which compare EU soft power assets with their own ones and those of EU competitors, the bloc's attractiveness has hardly decreased enough for them to revise their EU aspirations. Hence, the nowadays popular conventional wisdom that soon the EU is likely to no longer be an attractive power to align to seems, to a large extent, engendered by an amalgamation of relative and absolute perspectives on soft power. It does not appear, however, to be the only factor to generate this wisdom. 
What seems to also inflame the pessimism about the bloc's attractiveness is the fact that the EU, to date, is the world's most successful integration group and is often viewed as a model for regional integration (e.g., Lenz, 2012). Such a high status generates high, sometimes fairly excessive expectations from the bloc, especially in its external affairs (on the EU's capability-expectations gap see Hill, 1993) and as a result, any EU failure turns out be more notable than similar failures of other integration groups.

All in all, it hardly appears fair to speak of "the end of European soft power", like some analysts do (e.g., Sommerfeldt \& Zschäpitz, 2016). Rather, constantly changing domestic and international contexts keep bringing different aspects of the EU's attractiveness to the fore, giving importance to different competitive advantages of the bloc. In light of this, it is no surprise that nowadays, in the post-Brexit period, the vast majority of the target countries are keeping their European choice as their foreign policy priorities: as the then Serbian Prime Minister Aleksandar Vučić said in February 2016, the EU may have "lost its magic power" and "is not as attractive as it used to be, but we are rational people and we know this is the best for our country" (RFE/RL, 2016).

Concurrently, the fact that internal EU crises do not substantially affect its attractiveness in its neighborhood does not imply that neither do external factors. Illustrative of this point are two "outliers", that is, two countries that have got off the European way in recent years. As was mentioned above, the first factor, which turned Armenia away from the European path, is the EU's general weakness in the security field and inability to cope with other countries' hard power. The second factor is that the bloc tends to be flippant regarding who to rely on in the target countries, sometimes supporting politicians whose policies appear blatantly inconsistent with European values, which in the end undermines the EU's reputation. A vivid example of this point is Moldova, where the election of a pro-Russian President in November 2016 was mainly due to a popular disenchantment not with the EU itself, but unprecedentedly high corruption among the EU-oriented coalition which has governed the country since 2009 (e.g., Kostanyan, 2016). Remarkably, the EU's officials used to constantly support the coalition, calling the country under their governance "a success story", which in the end considerably lowered popular trust in the bloc in that country (Kostanyan, 2016). 


\section{Acknowledgements}

For their helpful comments and remarks, I would like to express my gratitude to the partakers of the workshop "Issues and Turning Points in Foreign Policy" at the 12th Annual Graduate Conference in Political Science, International Relations and Public Policy in Memory of the late Yitzhak Rabin (Hebrew University of Jerusalem, Israel), where an earlier draft of this paper was presented.

Artem Patalakh is a PhD candidate in Political Studies at the Graduate School of Social and Political Sciences of the University of Milan, Italy. He earned bachelor's and master's degrees in regional studies from MGIMO-University (Moscow State Institute of International Relations, Russia). His recent publications focus on Russian and EU foreign policies, integration processes in the post-Soviet space, soft power, democracy and human rights promotion.

\section{References}

Bodner, M. (2015), 'Putin's pivot: out of Ukraine, into Syria,' The Moscow Times, 24 December. Retrieved from https://themoscowtimes.com/articles/putins-pivotout-of-ukraine-into-syria-51330 [accessed 27 Jun 2017]

Bröning, M. (2016), 'The rise of populism in Europe: can the center hold?' Foreign Affairs, 3 June. Retrieved from https://www.foreignaffairs.com/articles/ europe/2016-06-03/rise-populism-europe [accessed 27 Jun 2017]

Chochia, A. \& Popjanevski, J. (2016), 'Change of power and its influence on country's Europeanization process. Case study: Georgia,' in T. Kerikmäe \& A. Chochia (eds.) Political and Legal Perspectives of the EU Eastern Partnership Policy, Cham: Springer, pp. 197-210. https://doi.org/10.1007/978-3-319-27383-9_13

Daly, J. (2014), 'Kazakhstan and Belarus: buyer's remorse?' in F. Starr \& S. Cornell (eds.) Putin's Grand Strategy: The Eurasian Union and Its Discontents, Washington: Central Asia-Caucasus Institute \& Silk Road Studies Program, pp. 82-97.

Eagly, A. H. \& Chaiken, S. (1993), The Psychology of Attitudes, Orlando, FL: Harcourt Brace Jovanovich.

Economides, S. \& Ker-Lindsay, J. (2015), “Pre-accession Europeanization”: the case of Serbia and Kosovo,' Journal of Common Market Studies, vol. 53, no. 5, pp. 1027-1044. https://doi.org/10.1111/jcms.12238 
Eisenegger, M. \& Imhof, K. (2008), 'The true, the good and the beautiful: reputation management in the media society,' in A. Zerfaß, B. van Ruler \& K. Sriramesh (eds.) Public Relations Research: European and International Perspectives and Innovations, Wiesbaden: VS Verlag für Sozialwissenschaften, pp. 125-146. https://doi.org/10.1007/978-3-531-90918-9_8

EIU (2016), Democracy Index 2015: Democracy in the Age of Anxiety, London: EIU Limited.

Emmott, R. \& Guarascio, F. (2016), 'Italy resists EU push for Russia sanctions over Aleppo bombings,' Reuters, 21 October. Retrieved from http:/www.reuters.com/ article/us-eu-summit-russia-idUSKCN12K2GK [accessed 28 Jun 2017]

Eriksen, E. \& Fossum, J. (2004), 'Europe in search of legitimacy: strategies of legitimation assessed,' International Political Science Review, vol. 25, no. 4, pp. 435-459. https://doi.org/10.1177/0192512104045089

European Commission (2014), Bosnia and Herzegovina Progress Report. Retrieved from https://ec.europa.eu/neighbourhood-enlargement/sites/near/files/pdf/key_ documents/2014/20141008-bosnia-and-herzegovina-progress-report_en.pdf [accessed 27 Jun 2017]

— (2016), 'Overview - Instrument for Pre-Accession Assistance.' Retrieved from https://ec.europa.eu/neighbourhood-enlargement/instruments/overview_en [accessed 27 Jun 2017]

Eurasian Economic Commission (2016), Evraziiskii ékonomicheskii soyuz v tsifrakh [Eurasian Economic Union in figures]. Retrieved from http://www. eurasiancommission.org/ru/act/integr_i_makroec/dep_stat/econstat/Documents/ Brief_Statistics_Yearbook_2016.pdf [accessed 27 Jun 2017]

Eurostat (2016), Europe in Figures: Eurostat Yearbook. Retrieved from http://ec.europa. eu/eurostat/statistics-explained/index.php/Europe_in_figures_-_Eurostat_ yearbook [accessed 27 Jun 2017]

- (2017), Real GDP Growth Rate: Volume. Retrieved from http://ec.europa.eu/ eurostat $/$ tgm/table.do?tab=table\&init=1\&language $=$ en $\&$ pcode=tec $00115 \&$ plug in $=1$ [accessed 27 Jun 2017]

Ferrin, M. \& Kriesi, H. (2014), Europeans' Understandings and Evaluations of Democracy: Topline Results from Round 6 of the European Social Survey, London: European Social Survey ERIC.

Forsberg, T. (2013), 'The power of the European Union: what explains the EU's (lack of) influence on Russia?' Politique européenne, vol. 39, no. 1, pp. 22-42. https://doi.org/10.3917/poeu.039.0022

Freedom House (2017), Freedom in the World 2017, Washington: Freedom House.

Getmanchuk, A. (2014), 'Tracing the origins of the Ukraine crisis: should the EU share the blame?' Europe's World, Summer 2014, pp. 78-82. 
Habermas, J. (1984), The Theory of Communicative Action, Volume 1: Reason and the Rationalization of Society, Boston, MA: Beacon Press.

Halmai, G. (2017), 'Second-Grade Constitutionalism? The Cases of Hungary and Poland,' CSF-SSSUP Working Paper Series, no. 1/2017.

Hilgard, E. (1980), 'The trilogy of mind: cognition, affection, and conation,' Journal of the History of the Behavioral Sciences, no. 16, pp. 107-117. https://doi.org/ 10.1002/1520-6696(198004)16:2<107::AID-JHBS2300160202>3.0.CO;2-Y

Hill, C. (1993), 'The capability-expectations gap, or conceptualizing Europe's international role,' Journal of Common Market Studies, vol. 31, no. 3, pp. 305-328. https://doi.org/10.1111/j.1468-5965.1993.tb00466.x

Hsu, A. et al. (2016), Environmental Performance Index, New Haven, CT: Yale University.

ITU (2016), Measuring the Information Society Report, Geneva: ITU. https://doi.org/10.1002/9781118445112.stat03789.pub2

Jones, S. (2015), 'Garibashvili opposes Georgia joining the EU sanctions against Russia,' Georgia Today, 7 August. Retrieved from http:/georgiatoday.ge/ news/883/garibashvili-opposes-georgia-joining-the-eu-sanctions-against-russia [accessed 27 Jun 2017]

Kakachia, K. \& Minesashvili, S. (2015), 'Identity politics: exploring Georgian foreign policy behavior,' Journal of Eurasian Studies, no. 6, pp. 171-180. https://doi.org/10.1016/j.euras.2015.04.002

Khidasheli, T. (2011), 'Georgia's European way,' Internationale Politik und Gesellschaft, no. 3, pp. 95-108.

Kostanyan, H. (2016), "Why Moldova's European integration is failing," CEPS Commentary, 3 March. Retrieved from https:/www.files.ethz.ch/isn/196230/ EU-Moldova\%20formatted.pdf [accessed 27 Jun 2017]

Kostanyan, H. \& Giragosian, R. (2016), 'EU-Armenian relations: seizing the second chance,' CEPS Commentary, 31 October. Retrieved from https://biblio.ugent.be/ publication/8514006/file/8514007.pdf [accessed 27 Jun 2017]

Laruelle, M. (2015), 'Russia's bedfellowing policy and the European far right,' Russian Analytical Digest, no. 167, pp. 2-5.

Lenz, T. (2012), 'Spurred emulation: the EU and regional integration in Mercosur and SADC,' West European Politics, vol. 35, no. 1, pp. 155-173. https://doi.org/10.1080/01402382.2012.631319

Manners, I. (2002), 'Normative power Europe: a contradiction in terms?' Journal of Common Market Studies, vol. 40, no. 2, pp. 235-258.

https://doi.org/10.1111/1468-5965.00353

Michalski, A. (2005), 'The EU as a soft power: the force of persuasion,' in J. Melissen (ed.) The New Public Diplomacy: Soft Power in International Relations, New York: Palgrave Macmillan, pp. 124-144. https://doi.org/10.1057/9780230554931_7 
Movchan, A. (2017), Decline, Not Collapse: The Bleak Prospects for Russia's Economy, Moscow: Carnegie Endowment for International Peace.

Müller, P. (2016), 'EU foreign policy: no major breakthrough despite multiple crises,' Journal of European Integration, vol. 38, no. 3, pp. 359-374. https://doi.org/10.1080/07036337.2016.1140157

Murtazina, Y. (2016), 'Italy's Veneto region calls to lift EU sanctions against Russia,' Russia Beyond the Headlines, 20 May. Retrieved from https://www.rbth.com/ international/2016/05/20/italys-veneto-region-calls-to-lift-eu-sanctions-againstrussia_594981 [accessed 28 Jun 2017]

Nielsen, K. (2016), Soft Power Europe: The Lesser Contradiction in Terms and Practices, $\mathrm{PhD}$ thesis, University of Tartu.

Nye, J. S. Jr (2004), Soft Power: The Means to Success in World Politics, New York: Public Affairs. (2011), The Future of Power, New York: Public Affairs. (2015), 'Foreword,' in W. Yasushi and D. McConnell (eds.) Soft Power Superpowers: Cultural and National Assets of Japan and the United States, New York: Routledge, pp. ix-xiv.

Oliver, T. (2017), 'The EU and Brexit: processes, perspectives and prospects,' in W. Outhwaite (ed.) Brexit: Sociological Responses, New York: Anthem Press, pp. 127-138.

Orenstein, M. \& Kelemen, D. (2017), 'Trojan horses in EU foreign policy,' Journal of Common Market Studies, vol. 55, no. 1, pp. 87-102. https://doi.org/10.1111/jcms.12441

Patalakh, A. (2016), 'Assessment of soft power strategies: towards an aggregative analytical model for country-focused case study research,' Croatian International Relations Review, vol. 22, no. 76, pp. 85-112.

https://doi.org/10.1515/cirr-2016-0007

(2017), 'Economic or Geopolitical? Explaining the Motives and Expectations of the Eurasian Economic Union's Member States,' Fudan Journal of the Humanities and Social Sciences, online first. https://doi.org/10.1007/s40647-017-0191-X

Popescu, N. (2011), 'How the eurozone crisis affects EU power,' European Council on Foreign Relations, 25 November. Retrieved from http://www.ecfr.eu/article/ commentary_how_the_eurozone_crisis_affects_eu_power[acce ssed 27 Jun 2017]

Porter, M. \& Stern, S. (2016), Social Progress Index 2016, Washington: Social Progress Imperative.

Prekic, A. (2014), 'Djukanovic: sanctions against Russia are wrong,' Independent Balkan News Agency, 28 November. Retrieved from http:/www.balkaneu.com/ djukanovic-sanctions-russia-wrong/ [accessed 27 Jun 2017]

RFE/RL (2016), 'Vucic Says EU Membership Has “Lost Magic Power” for Balkans,' 23 February. Retrieved from http://www.rferl.org/a/vucic-says-eu-membership-has- 
lost-magic-power-for-balkans-migrant-crisis-brexit/27568380.html [accessed 27 Jun 2017]

Rieker, P. (2016), 'Comparisons and conclusions,' in P. Rieker (ed.) External Governance as Security Community Building: The Limits and Potential of the European Neighbourhood Policy, London: Palgrave Macmillan, pp. 187-204. https://doi.org/10.1057/978-1-137-56169-5_8

Risse, T. (2000), “'Let's argue!”: communicative action in world politics,' International Organization, vol. 54, no. 1, pp. 1-39. https://doi.org/10.1162/002081800551109

Roberts, S. \& Moshes, A. (2015), 'The Eurasian Economic Union: a case of reproductive integration?' Post-Soviet Affairs, vol. 32, no. 6, pp. 542-565. https://doi.org/10.1080/1060586X.2015.1115198

Rohrbacher, T. \& Jeníčková, M. (2011), 'Is the EU attractive?' Central European Journal of International and Security Studies, vol. 5, no. 2, pp. 177-200.

Rostoks, T. (2015), 'Forms of Russian and EU power in the "New Eastern Europe",' in T. Rostoks \& A. Sprūds (eds.) The Different Faces of "Soft Power": The Baltic States and Eastern Neighborhood between Russia and the EU, Riga: LIIA, pp. 8-29.

Sadowski, R. (2013), Partnership in Times of Crisis: Challenges for the Eastern European Countries' Integration with Europe, Warsaw: OSW.

Smith, K. (2014), 'In the European Union's soft power in decline?' Current History, vol. 113, no. 761, pp. 104-109.

Sommerfeldt, N. \& Zschäpitz, H. (2016), 'Europa riskiert jetzt seinen letzten Trumpf,' Die Welt, 15 June. Retrieved from http://www.welt.de/wirtschaft/article156227666/ Europa-riskiert-jetzt-seinen-letzten-Trumpf.html [accessed 27 Jun 2017]

Szpala, M. (2014), 'Russia and Serbia - soft power and hard interests,' OSW Commentary, no. 150. Retrieved from https://www.osw.waw.pl/sites/default/files/ commentary_150.pdf [accessed 27 Jun 2017]

Telò, M. (2007), Europe: A Civilian Power? European Union, Global Governance, World Order, New York: Macmillan.

Tetlock, P. (1981), 'Pre- to postelection shifts in presidential rhetoric: impression management or cognitive adjustment?' Journal of Personality and Social Psychology, vol. 41, no. 2, pp. 207-212. https://doi.org/10.1037/00223514.41.2.207

Times Higher Education (2016), World University Ranking 2015-2016. Retrieved from https://www.timeshighereducation.com/world-university-rankings/2016/worldranking\#!/page/0/length/25/sort_by/rank/sort_order/asc/cols/stats [accessed 27 Jun 2017]

Transparency International (2016), Corruption Perceptions Index 2015. Retrieved from https:/www.iaca.int/images/news/2016/Corruption_Perceptions_Index_2015_ report.pdf [accessed 27 Jun 2017] 
Treaty of Lisbon Amending the Treaty on European Union and the Treaty Establishing the European Community, Official Journal of the European Union, C 306, 17.12.2007.

Tsybulenko, E. \& Pakhomenko, S. (2016), 'The Ukrainian crisis as a challenge for the Eastern Partnership,' in T. Kerikmäe \& A. Chochia (eds.) Political and Legal Perspectives of the EU Eastern Partnership Policy, Cham: Springer, pp. 167-180. https://doi.org/10.1007/978-3-319-27383-9_11

Tulmets, E. (2007), 'Can the discourse on "soft power" help the EU to bridge its capability-expectations gap?' European Political Economy Review, no. 7, pp. $195-226$.

UNDP (2016), Human Development Report 2016: Human Development for Everyone, New York: UNDP.

Vasilyan, S. (2017), “'Swinging on a pendulum": Armenia in the Eurasian Economic Union and with the European Union,' Problems of Post-Communism, vol. 64, no. 1, pp. 32-46. https://doi.org/10.1080/10758216.2016.1163230

Vuving, A. (2009), 'How soft power works,' Paper presented at the APSA's annual meeting, Toronto, Canada, 3 September. https://doi.org/10.2139/ssrn.1466220

Wierzbowska-Miazga, A. (2013), Support as a Means of Subordination: Russia's Policy on Belarus, Warsaw: OSW.

Zagorski, A. (2015), 'Caught between the economy and geopolitics,' in F. Hett \& S. Szkola (eds.) The Eurasian Economic Union: Analyses and Perspectives from Belarus, Kazakhstan, and Russia, Berlin: FES, pp. 4-7.

Żornaczuk, T. (2016), 'Forever on the periphery? The return of geopolitics to EU enlargement to the Balkans,' PISM Policy Paper, no. 6 (147). 